\title{
Exploration of local isolate of highly pathogenic avian influenza clade 2.3.2.1 as vaccine candidate to prevent mass outbreak in East Java
}

\author{
S. Suwarno ${ }^{\circledR}$, N.S. Widjaja and J. Rahmahani \\ Laboratory Virology and Immunology, Department of Microbiology, Faculty of Veterinary Medicine, University of \\ Airlangga, Surabaya, Indonesia
}

\begin{tabular}{l} 
Article information \\
\hline Article history: \\
Received June 14, 2020 \\
Accepted August 30, 2020 \\
Available online October 9, 2021 \\
\hline Keywords: \\
Avian Influenza \\
Subtype H5N1 \\
Clade 2.3.2.1 \\
Duck isolate \\
Chicken vaccine \\
\hline
\end{tabular}

\section{Correspondence:}

S. Suwarno

suwarno@fkh.unair.ac.id

\begin{abstract}
Highly Pathogenic Avian Influenza (HPAI) H5N1 is a major problem in poultry industry in many countries. It became endemic disease in Indonesia since 2003. Recently, research revealed that current circulate HPAI in Indonesia has switched from clades 2.1 to 2.3.2.1. To eradicate this disease, methods such as stamping out and quarantine seem not suitable applied since poultry industry is one of main sector in agricultural commodity in some areas such as Central Java, Yogyakarta, and East Java. It provides large of job opportunity for native people from rural to city areas. To prevent the morbidity of this disease, vaccination use local seed is primarily needed. This research was conducted to explore local isolate of HPAI clade 2.3.2.1 as vaccine candidate. Samples were obtained from some areas in East Java where outbreak occurred. Molecular characteristic according to Neuraminidase (N) gene was conducted. Samples has close relativity to circulating virus was used as seed vaccine then processed into killed vaccine production. It was challenged to observe the protectivity on poultry. The effectivity of the vaccine was measured through Haemagglutination Inhibition (HI) assay. The result of study showed that isolate DOD_3_2013 has close relativity to circulating virus thus it used as vaccine candidate. Challenged test showed that this vaccine candidate induced higher antibody titer compared to control. The average of antibody titer was $8.2(\log 2)$ with the protection level $100 \%$. It is concluded that this isolate could be used as vaccine candidate to eradicate HPAI clade 2.3.2.1 around East Java.
\end{abstract}

DOI: $10.33899 /$ ijvs.2020.127331.1498, CAuthors, 2021, College of Veterinary Medicine, University of Mosul.

This is an open access article under the CC BY 4.0 license (http://creativecommons.org/licenses/by/4.0/).

\section{Introduction}

According to OIE Terrestrial Animal Health Code (Terrestrial Code) Avian Influenza is defined as a disease infects poultry caused by any Influenza A virus which has IVPI score higher than 1.2 or any influenza $A$ virus caused mortality on 6-8 out of 10 of 4-8 weeks old chickens within 10 days of observation. They were categorized as Highly Pathogenic Avian Influenza (HPAI) which cause highly mortality rate. It is also caused by Influenza A virus belong to subtypes $\mathrm{H} 5$ and $\mathrm{H} 7$ which has similar amino acid sequence on cleavage site of hemagglutinin protein to other
HPAI isolate. They are categorized as Low Pathogenic Avian Influenza (LPAI) (1). It infects both human and poultry cause chaos on economy, health and social around the world (2). It became endemic disease and one of major problem in poultry farm (primarily rural area) in East Asia and South East Asia since 2003 (3) including Indonesia (4).

Since outbreak 2003, clade 2.1.3 is predominant clade caused all outbreak in poultry around 2003-2011. According to current research clade 2.1.3 is not predominant anymore. It is noticed that clade 2.3.2.1 is predominant clade which currently circulating in Indonesia (4). 
Clade 2.3.2.1 is not only predominant clade circulating in Indonesia. Its circulation expanding around East and Southeast Asia until Eastern Europe (5). To eradicate the disease method such as stamping out and quarantine are not suitable because poultry industry is one of major sector in agricultural commodity in some areas such as Central Java, Yogyakarta, and East Java (4). It provides $10 \%$ of job opportunity for native people from rural to city areas (6). Many countries have applied different strategy to control this disease such as quarantine, striating animal movement or importation, routine surveillance, collecting epidemiological data, stamping out and vaccination (7).

One of the most effective strategy is applying vaccination used local seed virus that has similarity $88-100 \%$ compared to predominant clade (8). Avian Influenza Virus (AIV) is enveloped negative-sense single stranded segmented RNA virus belong to genus Influenza Virus A from Orthomyxoviridae (9). Its genome encodes 11 proteins such as Polymerase protein (PA) and its subunit (PB2, PB1, PB1F2), Hemagglutinin protein (HA), Nucleoprotein (NP), Neuraminidase protein (NA), two types of Matrix protein (M1 and M2), Non-structural protein 1 (NS1) and Nonstructural protein 2 (NS2) or Nuclease Export Protein (NEP) $(10,11)$. Among those protein, HA and NA proteins which were located on the surface of lipid bilayer enveloped, are the main focus on many research, since they have roles on AIV pathogenesis, virulence, genotyping, and induction of antibodies (10).

This research was conducted to obtained local isolate of Highly Pathogenic Avian Influenza clade 2.3.2.1 as vaccine candidate to eradicate the circulating Avian Influenza from East Java.

\section{Materials and methods}

\section{Sample collection and molecular identification}

Samples of cloaca swabs, tracheal swabs and eggs were collected from 4 regencies which high density of bird population was recorded and frequent outbreak occurred. They were Mojokerto, Jombang, Sidoarjo and Blitar in East Java province. Samples were collected from cloaca and tracheal swabs, carcass and eggs. Samples were processed into RNA extraction (R\&A-BLUETM, inTRON BIOTECHNOLOGY) then RT-PCR using primer encoding Neuraminidase Protein (N) specifically genotyping N1 (detecting clade 2.3.2.1) (Table 1) (SuperScript® III OneStep RT-PCR System with Platinum ${ }^{\circledR}$ Taq DNA Polymerase, Invitrogen). All samples were processed into Agarose gel electrophoresis to observe the bands as the result of amplification. 1 kb Marker DNA was used (GeneRuler 1 kb DNA Ladder, ThermoFisher SCIENTIFIC). The Electrophoresis was conducted in $2 \%$ agarose gel and run on $125 \mathrm{~V}, 70 \mathrm{~mA}$ for $45 \mathrm{~min}$ (PowerPac Basic, BIO-RAD). Gel then observed under UV trans illuminator. Positive samples were processed into purification then sequenced (BigDyeTM Terminator v3.1 Cycle Sequencing Kit, ThermoFisher) run on automated sequencer ABI Prism 310. The obtained sequence was aligned on genetyx version 10. Homology analysis was conducted through nucleotide Basic Local Alignment Search Tool (BLAST) (NCBI) comparing isolated samples to Avian Influenza Virus (AIV) from Indonesia submitted into Genbank around 2005-2013. Phylogenetic tree was constructed using Molecular Evolutionary Genetics Analysis 5 (MEGA5) and TreeGraph2. Isolate has close relation to circulating AIV was chosen to be seed vaccine candidate.

Table 1: Sequence of primer for amplification. The primer pairs were designed to genotyping N1 subtype

\begin{tabular}{lrccc}
\hline Primer & nucleotides sequence & Region & Sense & Weight \\
\hline NA_1F & 5'-TGTAAAACGACGGCCAGTAGCRAAAGCAGGAGTTYAA-3' & $2-37$ & + & \multirow{2}{*}{$761 \mathrm{bp}$} \\
NA_1R & 5'-CCTCRTARTGRTAATTAGGRG- 3' & $743-763$ & - & \\
NA_2F & 5'-AGCCYTRYTGAATGACAARC- 3' & $416-435$ & + & \multirow{2}{*}{$516 \mathrm{bp}$} \\
NA_2R & 5'-YTGATTGAAAGAYACCCATGG- 3' & $912-932$ & - & \\
NA_3F & 5'-CAYTAYGAGGARTGCTCCTG- 3' & $782-802$ & + & \multirow{2}{*}{$676 \mathrm{bp}$} \\
NA_3R & 5'-AGTAGAAACAAGGAGTTTTT- 3' & $1439-1458$ & - & \\
\hline
\end{tabular}

\section{Seed vaccine propagation}

The vaccine candidate was processed into vaccine formulation. The isolate was inoculated into 10 days old embryonated egg for virus propagation (one passage). After incubation for 5 days the allantoic fluid was obtained for further processing

\section{Virus titration and vaccine formulation}

The allantoic fluid was processed for virus titration on embryonated eggs (12). Each positive samples were diluted into 10-1 until 10-10. Then they were inoculated into 5 embryonated eggs. To know the titer of the virus, the result was measured through Reed and Muench method. After titration, the seed virus was processed into sterility test to ensure it's free from bacterial contamination. It was cultured into Thioglycolate Agar and Nutrient Agar. After confirming the sterility of seed from bacterial contamination, the virus was processed into stability test by freezing and thawing it. The processes were conducted on 1st month, 2nd month, 3rd month, 4th month, 5th month and 6th month. After the stability test, the seed virus was processed into re titration as mentioned before. The virus was inactivated using $0.1 \%$ 
formalin. The mixture was stirred on $4^{\circ} \mathrm{C}$ for 24 hours. To confirm the virus perfectly inactivated, it was inoculated intramuscularly into 10 Specific Pathogen Free (SPF) chickens to observe the clinical signs may appear. Inactivated seed virus was expected to not cause any clinical signs of HPAI infection in infected chicken. After confirming that the seed vaccine was perfectly inactivated, the vaccine formulation was arranged. Montanide was used as the adjuvant. The expected final titer of the formulation was $105 \mathrm{EID} 50 / \mathrm{ml}$. The comparison between adjuvant and the seed was 70:30.

\section{Protectively test}

The vaccine was tested by injecting the vaccine into 60 SPF chicks to reveal the immunogenicity effect. Vaccine of AIV commonly applied was used as control (subtype H5N1, CAPRIVAC AI-K®, SANBE). The titer of injected vaccine was $105 \mathrm{EID} 50 / \mathrm{ml}$. Chicken were vaccinated by intramuscular route at 2 weeks old, 4 weeks old, 6 weeks old, and 8 weeks old. The antibody titer was measured through Haemagglutination Inhibition Assay once a week. Then challenge test was applied using pathogenic AIV (Ck/Indonesia/BL/03) (13). The observation was conducted to know mortality rate of the chicken infected by AIV and the capability of vaccine to minimize clinical signs due to infection.

\section{Result}

Sample collection and molecular identification

Samples were collected from 4 regencies with high density of bird's population. Samples were consisted of cloaca and tracheal swabs 37 , carcass included some specific organs such as lungs 13 , and eggs 120 . They were consisted of poultry and some exotic birds (Table 2). All the samples were processed into RNA extraction then Reverse Transcriptase-Polymerase Chain Reaction (RT-PCR) genotyping for $\mathrm{N} 1$ The amplicon was visualized into $2 \%$ agarose electrophoresis gel (Figure 1-3). The positive sample marked by the presence of band. Three pairs of primers were designed for genotyping N1 protein. According to RT-PCR three out of 170 samples were showed positive result. They were marked as MN_3_2013, AB_1_2013, and DOD_2_2013. It was marked by the presence of bands of each sample (Figure 4). The presence of band of each sample meant that the samples were belong to N1 subtype.

\section{Seed vaccine propagation}

After the isolate had been identified, it was subjected to propagation stage to ensure that the final of virus titer met the requirement. The propagation was performed in embryonated eggs. The result of propagation showed that the final titer was 107.10 (EID50). This final titer met the requirement.

Table 2: Details of samples were collected from Mojokerto, Jombang, Sidoarjo and Blitar

\begin{tabular}{llccc}
\hline Region & Species & No. of samples & Type of sample & Clinical signs \\
\hline \multirow{5}{*}{ Sidoarjo } & Day Old Duck & 3 & lungs & Sudden death \\
& Bangkok Chicken & 8 & Swab & - \\
& Erinus canaria & 2 & Swab & - \\
& Grey-cheeked Bulbul (Alophoixus bres) & 1 & Swab & - \\
& Agapornis & 4 & Swab & - \\
& Parakeet (Conuropsis carolinensis) & 4 & Swab & - \\
& Bekisar (Gallus varius) & 1 & Swab & - \\
\hline \multirow{3}{*}{ Jombang } & Muscovy Duck & 10 & Swab & - \\
& Ras chicken (Gallus gallus domesticus) & 3 & carcass & - \\
& Day Old Duck & 3 & carcass & - \\
\multirow{3}{*}{ Mojokerto } & Day Old Duck & 5 & Swab & - \\
& Ayam Ketawa (Laughing chicken) & 1 & Swab & - \\
& Copsychus saularis & 1 & Swab & - \\
\hline \multirow{5}{*}{ Blitar } & Ras chicken (Gallus gallus domesticus) & 4 & Lungs, brain & Torticolis, death \\
& Duck & 30 & eggs & - \\
& Ras chicken (Gallus gallus domesticus) & 30 & eggs & - \\
& Native chicken (Gallus gallus domesticus) & 30 & eggs & - \\
& Quail & 30 & eggs & - \\
\hline
\end{tabular}

Virus sterility test, titration, safety test and vaccine formulation

After performing virus propagation, the virus stock was tested for the sterility and the stability enduring freezingthawing mechanism. The sterility test was performed by culturing the virus into some designated media to confirm that the virus containing media was sterile and not containing hazard material or any bacteria contaminant. Further, the virus stock was subjected for stability test that performed for six months. According to stability test, on the first month of 
the test, the titer was reduced from 107.10 (EID50) into 106,10 (EID50). Even though the titer reduced, but it still met the requirement. Then, the seed vaccine candidate was subjected for safety test.

This test was performed to ensure that the seed vaccine candidate is safe to be injected to the chicken. The safety test showed that the chicken that received 105EID50/ml doze of vaccine was healthy and not death. After that the vaccine was formulated. Montanide was chosen to be the adjuvant. The comparison between adjuvant and the seed vaccine was 70:30.

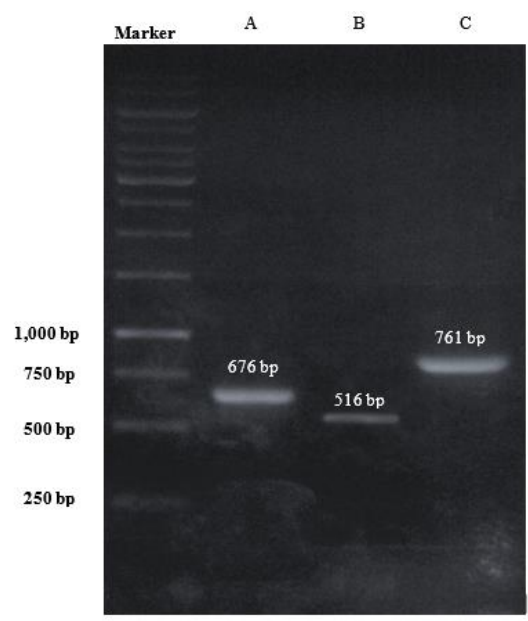

Figure 1: Result of Reverse Transcriptase-PCR of MN_3_2013. All primer sets could detect this sample. It means the sample belonged to subtype N1. A: NA3; B:NA2; C: NA3.

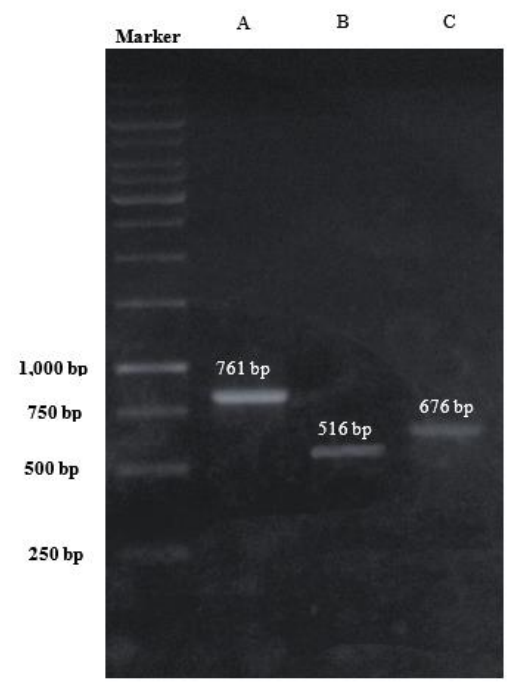

Figure 2: Result of Reverse Transcriptase-PCR of AB_1_2013. All primer sets could detect this sample. It means the sample belonged to subtype N1. A: NA1; B: NA2; C: NA3.

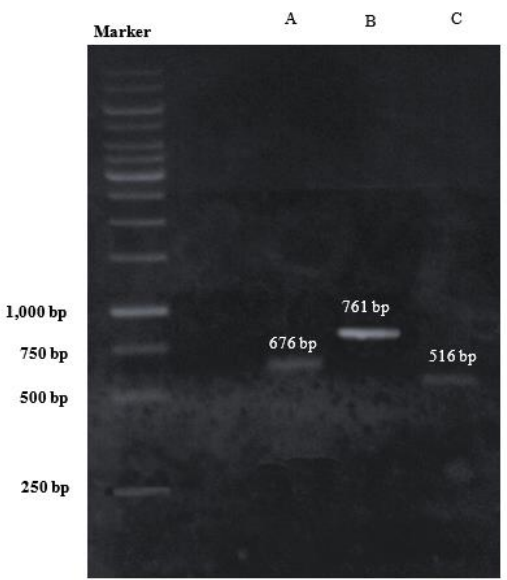

Figure 3: Result of Reverse Transcriptase-PCR of DOD_2_2013. All primer sets could detect this sample. It means the sample belonged to subtype N1. A: NA3; B: NA1; C: NA3.

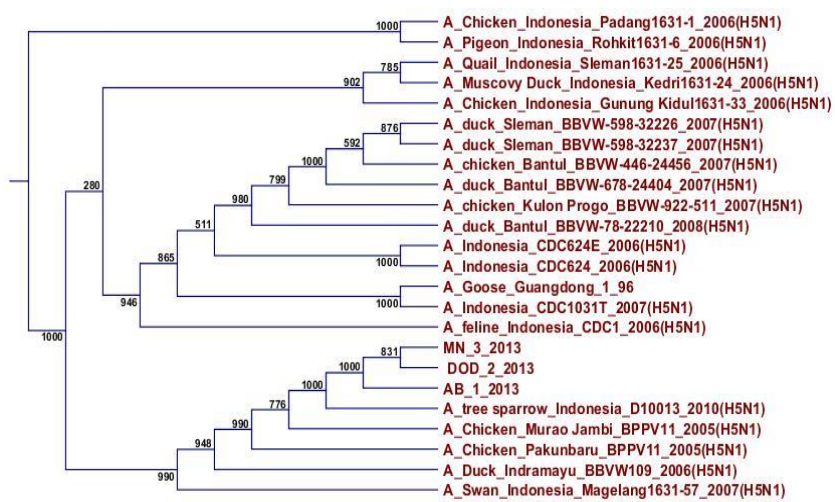

Figure 4: Phylogenetic tree of isolated samples compared to H5N1 Avian Influenza Virus submitted in GenBank. Isolated samples (marked by yellow box) formed distinct group compared to other AIV from Indonesia. It shared same ancestor to some AIV marked as green color.

The final titer of the vaccine was $105 \mathrm{EID} 50 / \mathrm{ml}$. It was tested by injecting the vaccine into 60 of SPF chicken. During eight weeks of observation, the control group that administered by classical vaccine having decreasing amount of antibody titer. The antibody titer reduced from 0.55 on the first week to 0.25 on the last week.

On the other hand, the group that vaccinated by formulated vaccine having increase of the level of antibody. On the first week, the titer of the antibody was 0.55. it increases in the second week into 101.55, 103.6, 104.5, 105.7, 106.2, 106.9, and 107.8 respectively.

On the last period of observation, the antibody titer of this group was 108.2. This result proved that the seed vaccine candidate was safe to be administered to the chicken. 


\section{Protectivity test}

After meeting the requirement of safety test. The challenge test was performed to proof that the new vaccine formulation could protect the chicken without giving rise any symptoms. The challenge test was performed on 20 chickens. The result showed that the new formulated vaccine could induce higher antibody titer 108.2 than the classical one. The new formulated vaccine did not give any side effect or symptoms.

\section{Discussion}

According to homology analyses the samples shared 9499\% of homology score compared to AIV (clade 2.1) in Indonesia. While homology score within isolate was $98-99 \%$ which means they have close identity.

According to phylogenetic tree MN_3_2013 and DOD_3_2013 shared same ancestor. It is proved by $99 \%$ of homology score between MN_2_2013 and DOD_3_2013. Both isolates were separated from AB_1_2013. The evolution distance within was $0,2 \%$. It is noticed that MN_2_2013 and DOD_3_2013 belong to same ancestor even though isolated from different species. All the isolated samples formed distinct. They tend to be identic to tree sparrow, chicken Muaro Jambi, chicken Pekanbaru, duck Indramayu and goose Magelang which were isolated around 2005-2010. It came up with new suggestion that clade 2.3.2.1 may already been circulated in Indonesia since 2005, but it has not become predominant clade yet. RNA viruses are lack of proofreading during its genome synthesis, thus it forms varieties in genomic population called quasi species (14). This founding may give small hind how outbreak caused by HPAI clade 2.3.2.1 occurred in poultry farm. This clade frequently found infecting waterfowl bird such as Baikal teals, whooper swans, mandarin ducks, white-fronted geese and spot-billed ducks (15). There is no clear evidence how this virus transmitted into poultry farm, even though there is no possibility of direct contacts between such birds to poultry. It was noticed virus transmission could possibly occur during poultry or poultry product movement (16). Since AIV genome consists of several segments of nucleic acid which both antigenic shift and antigenic drift commonly happen during replication (17).

According to molecular analyses, all isolated samples belong to clade 2.3.2.1. which became endemic since 2012 . It formed new cluster which not mutated from clade 2.1 (18). This founding adds the cluster varieties of AIV in Indonesia. This new clade tends to infect water fowl. It is noticed that water fowl tend to be resist from infection clade 2.1. Infection of clade 2.3.2.1 on waterfowl is rarely causing clinical signs while the infection of this clade on poultry or other terrestrial birds could result severe clinical signs. This founding also forms new suggestion that using local seed vaccine to eradicate this virus is needed.
Manufacturing vaccine is a challenging process which the manufacturer should ensure the safety, effectivity, and stability of the production cycle $(19,20)$. Among isolated samples, sample marked as DOD_2_2013 was chosen as seed vaccine candidate. Common medium for cultivating the virus is 11 day-old Specific Pathogen Free (SPF) embryonated chicken eggs. Inoculated eggs then incubated for certain period thus virus could propagate completely $(1,21)$. After propagation, alantoic fluid was obtained. Before It is processed into vaccine formulation, the titer of virus must be measured. It is done to know the number of virus already propagated. Currently, improvement for cultivating the virus is switched from embryonated-egg based production into cell line based production (21). The types cell line usually for cultivating influenza A viruses are Madine Darby Canine Kidney (MDCK), African Green Monkey Kidney (VERO), and Newborn Swine Kidney (NSK). The use of primary cell lines and continuous cell line in order to propagate the virus give advantages, primarily for those virus which cannot be isolated in chicken embryonated egg (22).

According to Reed and Muench method, the virus has titer 107.10 (EID50). During vaccine production, there are many chances the titer would decrease due to the processes and handling the material. Regarding to these possibilities, before processing the virus into vaccine formulation, virus propagation must be conducted properly, thus in the final process the amount of virus in the vaccine dose remain high in order to induce humoral antibody which capable to protect the poultry from AIV infections. There are difference of propagation capability of each virus which affects the virus titer. In Newcastle Disease Virus (NDV) which have genotype diversity among birds, according to similar experimental, NDV origin from pigeon (Pigeon/1984) which propagated in chicken embryonated egg has lower titer (106.9 EID50) compared to other isolate which isolated from poultry and waterfowl (23). According to this findings, it is important to keep the virus titer as high as possible so in the final process the amount of virus which deliver to the poultry could induce protective antibody against AIV. After titration, the seed was examined according some indicators such as infectivity, specify, and sterility. These examinations were conducted to ensure that manufactured vaccine is not contaminated and harmful for the poultry. Quality control tests obligated to be conducted. It consists of safety, purity, and sterility tests of the vaccine (21).

Titrated allantoic fluid was processed into sterility test to confirmed it was free from bacterial contamination. It was inoculated into Thioglycolate Agar and Nutrient agar. There is no colony formation on both agars that meant It was free from bacterial contamination. Sterility of vaccine is important because this product is administered for living things such as human and animals (WHO). It could be cultivated into some different medias for ensuring the seed was free from bacterial contamination. These media are 
Iraqi Journal of Veterinary Sciences, Vol. 36, No. 1, 2022 (1-7)

Tryptic Soya Agar (TSA), Macconkey Agar (MA), Salmonella Shigella Agar (SSA), Tryptic Soya Broth (TSB) (24).

After confirming that the seed vaccine was free from bacterial contamination, the seed vaccine was tested its stability on freezing-thawing condition. The result showed the decreasing of virus titer from 107.10 (EID50) into 106,10 (EID50). The reduction of the virus titer was begun since the first month of examination period. Even though the titer was decreasing, it still remained high. It means that the stability of seed vaccine is remained good during freezing-thawing treatment for 6 months. It is important because during handling of the vaccine, thermal change could be lowering seed stability, thus administered vaccine could not induce protective antibody. Indonesia is tropical country which has warm temperature (around $32^{\circ} \mathrm{C}$ ). Regarding this factor, it is important to use seed vaccine that have good stability over thermal stress.

After the stability examination, it was re-titrate into SPF embryonated egg, then processed into deactivation using $0.1 \%$ formalin. To ensure deactivation perfectly conducted, the deactivated virus was injected into 10 SPF chicken to know the presence of the clinical signs caused by active virus. The absence of clinical signs means that all the virus completely deactivated. Deactivation of the virus is important since the seed can cause severe clinical to mortality signs in poultry. If this step failed to deactivate all the virus, the virus would conduct replication inside the chicken that would be shed through nasal discharge and feces then contaminated the environment.

According to the result of antibodies titer, formulated vaccine could induce better Immunity. HI assay of chicken administered by formulated vaccine has higher antibodies titer compared to chicken administered by control vaccine. The challenge test was conducted administration of chicken with circulating HPAI. Surprisingly there is no mortality recorded on chicken administered by formulated vaccine. In contrast, all chicken administered by control vaccine were dead. It showed that formulated vaccine could induce better immunity and last longer compared to control vaccine.

\section{Conclusions}

To eradicate Avian Influenza, it is needed to use seed vaccine that has high identity to circulating AIV. According to the result, isolate DOD_2_2013 could give protection toward AIV infection. This isolate was obtained from waterfowl which cause subclinical signs but could infect poultry too. It could give better protection than conventional vaccine usually administered to poultry.

\section{Acknowledgement}

We would like to thank you to Ministry of Higher Education, University of Airlangga, and Faculty of
Veterinary Medicine for the support. This research was funded by DIPA BOPTN according to statement letter number 8714/UN3/KR/2014.

\section{Conflict of interest}

The author of this manuscript stated there is no conflict of interest regarding the writing process or data analysis.

\section{References}

1. OIE) World Organization for Animal Health, Avian Influenza (Infection with Avian Influenza Viruses, Manual of Diagnostic Tests and Vaccines for Terrestrial Animals.2016:1-23.

2. Patel RB, Mathur MB, Gould M, Uyeki TM, Bhattacharya J, Xiao Y, Khazeni N. Demographic and Clinical Predictors of Mortality from Highly Pathogenic Avian Influenza A (H5N1) Virus Infection. PLos ONE. 2014;9(3):1-10. DOI: 10.1371/journal.pone.0091630

3. Chua TH, Leung CYH, Fang HE, Chow CK, Ma SK, Sia SF, Ng IHY, Fenwick SG, James CM, Chua SB, Chew ST, Kwang J, Peiris JSM, Ellis TM. Evaluation of a Subunit H5 Vaccine and an Inactivated H5N2 Avian Influenza Marker Vaccine in Ducks Challenged with Vietnamese H5N1 Highly Pathogenic Avian Influenza Virus. Influenza Res Treat. 2010;2010:1-10. DOI: 10.1155/2010/489213

4. Dharmayanti NLPI, Pudjiatmoko RH, Wibawa H, Hardiman, Balish A, Donis R, Davis CT, Samaan G. Genetic Characterization of Clade 2.3.2.1 Avian Influenza A(H5N1) Viruses Indonesia. Emerg Infect Dis. 2014;20(7):671-674. DOI: 10.3201/eid2004.130517

5. Ducatez M, Sonnberg S, Crumpton JC, Rubrum A, Phommachanh P, Douangngeun B, Peiris M, Guan Y, Webster R, Webby R. Highly pathogenic avian influenza $\mathrm{H} 5 \mathrm{~N} 1$ clade 2.3.2.1 and clade 2.3.4 viruses do not induce a clade-specific phenotype in mallard ducks. J General Virol. 2017;98(6);1232-1244. DOI: $10.1099 / \mathrm{jgv} .0 .000806$

6. Ferlito C, Respatiadi H. Policy Reform on Poultry Industry in Indonesia. Centre for Indonesian Policy Studies;2019.

7. Vapnek J. Regulatory Measures Against Outbreaks of Highly Pathogenic Avian Influenza. Food Agriculture Organization (FAO) Legal Online Papers.2010;82:1-27.

8. Swayne DE. Principles for Vaccine Protection in Chickens and Domestic Waterfowl against Avian Influenza, Emphasis on Asian H5N1 High Pathogenicity Avian Influenza. Ann Acad Sci. 2006;1081:174-181. DOI: 10.1196/annals.1373.021

9. Yin J, Liu S, Zhu Y. An Overview of the Highly Pathogenic H5N1 Avian Influenza Virus. Virol Sci. 2013;28(1):003-015. DOI: 10.1007/s12250-013-3294-9

10. Nayak B, Kumar S, DiNapoli JM, Paldurai A, Perez AR, Collins PL, Samal SK. Contribution of the Avian Influenza Virus HA, NA and M2 Surface Proteins to the Induction of Neutralizing Antibodies and Protectivity Immunity. J Virol. 2010;84 (5):2408-2420. DOI: 10.1128/jvi.02135-09

11. Abbas M, Abidin ZU. Proteins of Influenza Virus: A Review. J Inf Mol Biol. 2013;1(1):1-8.

12. Spackman E, Killian ML. Avian Influeanza Virus Isolation, Propagation and Titration in Embryonated Chicken Eggs in Animal Influenza Virus. Meth Molecul Biol. 2014;1161:125-140. DOI: 10.1007/978-1-4939-0758-8 12

13. Li KS, Guan Y, Wang J, Smith GJD, Xu KM, Duan L, Rahardjo AP, Puthavathana P, Buranathai C, Nguyen TD, Estoepangestie ATS, Chalsingh A, Auewarakul P, Long HT, Hanh NTH, Webby RJ, Poon LLM, Chen H, Shortridge KF, Yuen KY, Webster RG, Peiris JSM. Genesis of A Highly Pathogenic and Potentially Pandemic H5N1 Influenza Virus in Eastern Asia. Nature. 430:209-213. DOI: 10.1038/nature02746

14. Knipe DM, Howley PM. Fields Virology. $6^{\text {th }}$ ed. Philadelphia: Lippincott Williams and Wilkins; 2013. 254 p. 
15. Choi JG, Kang HM, Jeon WJ, Choi KS, Kim KI, Song BM, Lee HS, Kim JH, Lee YJ. Characterization of Clade 2.3.2.1 H5N1 Highly Pathogenic Avian Influenza Viruses Isolated from Wild Birds (Mandarin Duck and Eurasian Eagle Owl) in 2010 in Korea. Viruses. 2013;5:1153-1174. DOI: $10.3390 / v 5041153$

16. Durr PA, Indriani R, Selleck P, Adjid ARM, Syafriati T, Ignjatovic J. Developing Farm-Level Post-vaccination Sero-Monitoring Systems for H5N1 Highly Pathogenic Avian Influenza in an Endemically Infected Country. Front Vet Sci. 2019;5:324. DOI: 10.3389/fvets.2018.00324

17. El-Shesheny R, Kandeil A, Bagato O, Maatouq AM, Moatasim Y, Rubrum A, Song MS, Webby J, Ali MA, Kayali G. Molecular characterization of avian influenza $\mathrm{H} 5 \mathrm{~N} 1$ virus in Egypt and the emergence of a novel endemic subclade. J General Virol. 2014;95:1444-1463. DOI: 10.1099/vir.0.063495-0

18. Wibawa H, Prijono WB, Irianingsih SH, Dharmayanti NLPI, Miswati Y, Safritria, Rochmah A, Daulay RSD, Andesyha E, Romlah. Disease outbreak investigation on duck in Central Java, Yogyakarta, and East Java: Identification of A New Virus Clade Subtype H5N1 Avian Influenza in Indonesia. J Atani Tokyo. 2012;12(2):34-39.

19. Robinson JM. Vaccine Production: Main Steps and Considerations. San Diego: Academic Press ;2016. 77-96 p.

20. Plotkin S, Robinson JM, Cunningham G, Iqbal R, Larsen S. The Complexity and Cost of Vaccine Manufacturing-An Overview. Vaccine. 2017;35:4064-4071. DOI: 10.1016/j.vaccine.2017.06.003

21. Gomez PL, Robinson JM, Rogalewicz JA. Vaccine Manufacturing. Vaccines. 2013:44-57. DOI: 10.1016/B978-1-4557-0090-5.00019-7

22. Lombardo T, Dotti S, Renzi S, Ferrari M. Susceptibility of Different Cell Lines to Avian and Swine Influenza Viruses. J Virol Methods. 2012;185:82-88. DOI: 10.1016/j.jviromet.2012.06.008

23. Miller PJ, King DJ, Afonso CL, Suarez DL. Antigenic Differences Among Newcastle Disease Virus Strains of Different Genotypes Used in Vaccine Formulation Affect Viral Shedding After a Virulent Challenge. Vaccine. 2007;25:7238-7246. DOI: 10.1016/j.vaccine.2007.07.017

24. Zia S, Mehmood MD, Anwar H, Gul S, Rafique E. Influence of Immunogen Count to Antibody Response of Inactivated Avian Influenza Virus Oil Based Vaccine in Broilers. Indian J Microbiol Res. 2019;6(1):44-49. DOI: 10.18231/2394-5478.2019.0010

\section{الكشف عن العزلة المحلية من فايروس أنفلونزا

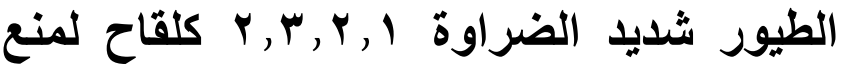 الاندلاعات المرضية على نطاق واسع الب في جاوة

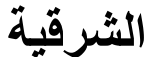

\author{
سوارنو سوارنو، ناتك سياتتيا وجاجا، جولا رحماني \\ مختبر الفايروسات والمناعة، فرع الاحياء المجهرية، كلية الطب \\ البيطري، جامعة اير لانجا، سور ابايا، إندونيسيا الاحياء \\ الخلاصة
}

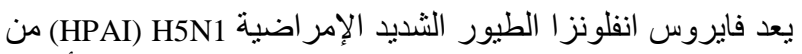

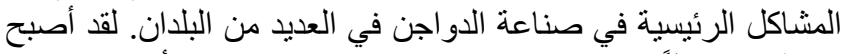

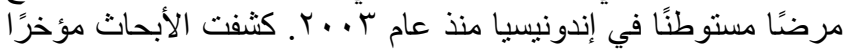

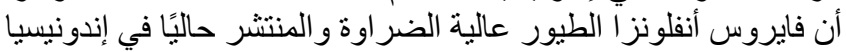

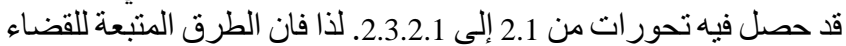

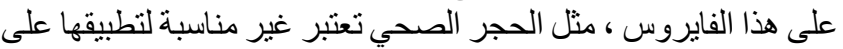

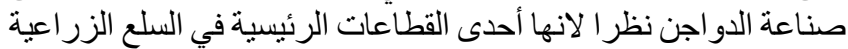

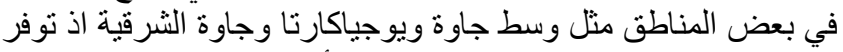

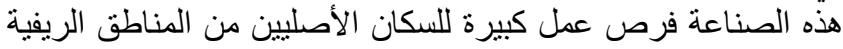

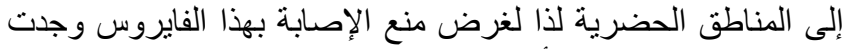

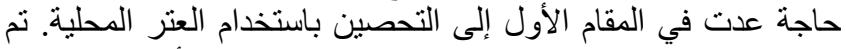

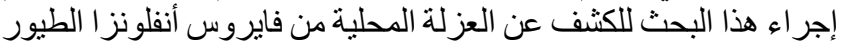

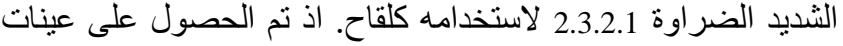
من بعض المناطق في جاوة الثرقية حيث حدثت الاندلاعات المرضية كرضية

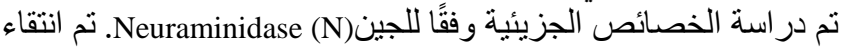

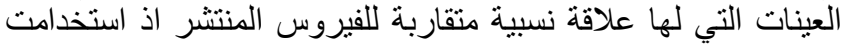

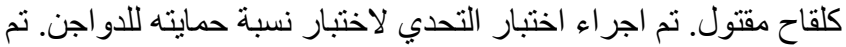

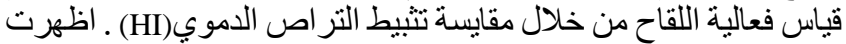

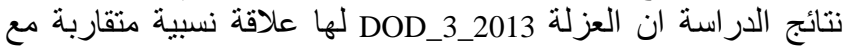

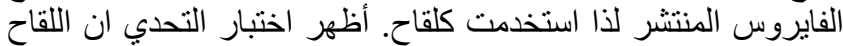

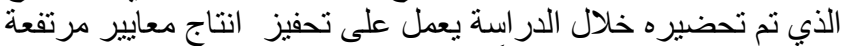

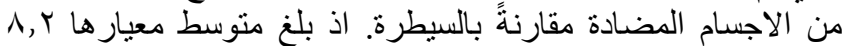

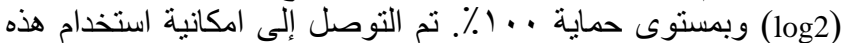

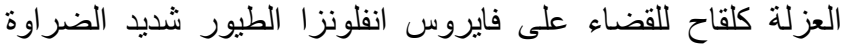
2.3.2.1 حول منطقة جاوة الثرقية. 